\title{
The CFA Franc Devaluation and Output Growth in the Franc Zone
}

\author{
Fouopi Djiogap Constant \\ Faculty of Economic and Management \\ University of Yaounde II \\ Cameroon \\ Tel: +237-743-442-16Ｅ-mail:constantfouopi@yahoo.fr
}

Received: July 10, 2011

Accepted: August 18, 2011 Published: January 5, 2012

doi:10.5430/ijfr.v3n1p40

URL: http://dx.doi.org/10.5430/ijfr.v3n1p40

\begin{abstract}
The objective of this paper is to assess the relationship between the devaluation of the CFA franc and output growth in the Franc Zone (note1). Hinging on the works carried out in Latin America and Asia, the article employs a pool data model to verify, if the January 12th, 1994 CFA franc devaluation had an impact on the output growth in these countries. Our results show that this devaluation had no impact on output growth. This can be explained by the fact that the real adjustment which should have preceded it failed.
\end{abstract}

Keywords: Devaluation, Economic Growth, Real Adjustment, Franc Zone

\section{Introduction}

The traditional theory of balance of payments stipulates that a monetary devaluation (note 2) would improve the competitiveness of the domestic products and would restore the balance equilibrium of the balance of trade. Indeed, the consequent change of the relative prices would directly lead to an increase in demand from abroad and to a replacement of imported goods by domestic goods in the local market. The result is not limited only to an increase in export and to a decline in import. Due to the multiplier phenomenon, this increases in demand of export goods and substitute's goods over the totality of the economy and would end afterward in an increase in the global demand, which in return would stimulate economic activity.

By relying on this vision, the International Monetary Fund (IMF) introduced the monetary devaluation as a component of the stabilization program to be applied in certain developing countries. This political reorientation faced a lot of criticisms from researchers and political leaders. These latter consider that the restoration of the balance of equilibrium in the balance of trade through currency devaluation is expensive in terms of production and employment. They advanced several arguments, such as the contraction of the demand; further to a redistribution of income in favor of the actors for strong marginal inclination to be saved and the braking finally reducing the supply due to the increase of the cost of imported of inputs. These reasons are used to explain that instead of being an economic control lever, the devaluation would rather cause a degradation or a slowing down of the economic activity.

The devaluation of the CFA franc which intervened in January, 1994 raised numerous controversies. Before this date, the African Countries of the Franc Zone lost market shares with regard to their Asian or African competitors who had all considerably devalued their currency during the 80 s. A good number of studies found that "the real adjustment " and the policy of competitive deflation had affected their limits and that only a currency adjustment would allow to durably reduce the deficits (Nashashibi, Bazzoni, 1994). On the other hand, the possibilities of replacement of import and the elasticities of export seemed low, the controversial legitimacy of the governments could be the worry of an inflationary skid, the development of fraud and fiscal lack of civic virtue, and finally a severe contraction of income. The devaluation could be "contractionary", according to a configuration known for several Latin American countries.

However, empirical literature does not unanimous give answer to the question relative to the effect of devaluation on the real sector. Concerning the empirical studies on the data of developing countries, a first group of authors (Connolly, 1983; Kamin, 1988; Bahmani-Oskooee and Rhee, 1997) still supports the traditional thesis of an expansionist effect of devaluation. A second group (Krueger, 1978; Gylfason, 1987, Edwards 1989a) did not find significant impact of devaluation on production. The last group of authors (Diaz-Alejandro, 1965; Cooper, 1971a; Edwards, 1989b; Agenor, 1991, Morley, 1992; Bahmani-Oskooee ( 1996) asserts that devaluation leads to a contraction of activities in these countries. This difference in results led Bahmani-Oskooee and Miteza ( 2003 ) to conclude that the results of empirical 
studies relative to the impact of devaluation on production differ from country to country and depend on the model as well as on the technique of estimation used.

Seventeen years after the devaluation, it is important to make a balance sheet and look into the future. Lived as a real trauma by the populations of zones WAEMU (the West African Economic and monetary Union) and CAEMC (Central Africa Economic and Monetary community), the devaluation of $50 \%$ of the CFA franc was justified by the increasing disconnection between the fundamental of savings for both zones and the value of the CFA franc. This disconnection became famous in the time for structural deficits of the balance of payments further to the loss of competitiveness of savings, degradation of economic performances and the continues fall in international reserves.

The cover rate for the monetary issue of the CFA franc was lower than $20 \%$, what was against the agreements of the Account of Operations which bind the French Treasury to the central banks BCEAO (Central Bank of the States of western Africa) and BEAC (Bank of the States of Central Africa). Furthermore, the political context of that time, illustrated by the "doctrine of Abidjan (note 3) ", widely favored the adoption of the principle of devaluation and its application.

Today, we can wonder if devaluation did allow to place the savings of the Franc zone countries on a path of high and long-lasting growth?

To this question, is added the persistent rumors relative to the imminence of a new devaluation of the CFA franc. Besides, the stiff anchoring of the CFA franc to the Euro which also seems to raise problems of competitiveness in the export of the countries of the Franc zone, as far as the US Dollar remains the reference currency of international commercial transactions. On the contrary, the fastening from the CFA franc to the Euro allowed savings importers of the Franc zone, to support better the major exogenous shock than the vertiginous increase of the price of a barrel of oil established in the first half of 2008.

To our knowledge no similar empirical analysis was led for CFA franc countries. It is thus to fill this gap that the present study will bring additional explanations on the question issue of devaluation impact in the franc zone.

The rest of the paper is organized as follows: the second section provides a brief overview of empirically related work; the third section presents the main methodological issues and the fourth section presents the main econometric results of our study.

\section{Literature Review}

The relationship between the level of output and the real exchange rate is an important and controversial issue for economies. Economists have been studying the relationship between the real exchange rate and the level of output because currency devaluation is often considered to be a tool for improving the foreign sector of an economy. It is argued that a devaluation or depreciation of a currency raises the price of imports compare to that of exports, and this causes the trade balance to improve. This leads to an improvement in the foreign sector of the economy. The improvement in the foreign sector raises output and employment in the overall economy. According to the traditional views such as the elasticities, absorption, and the Keynesian argue that devaluations have expansionary effect on output and aggregate demand.

Contrary to the traditional view, there are also other theoretical reasons why devaluation can have a contractionary impact on economic activity. First, devaluation can redistribute income from groups with a lower to a higher marginal propensity to save. This may lead to a decline in aggregate demand and output (Krugman and Taylor, 1978). Secondly, a nominal devaluation can decrease the aggregate demand through the negative real balance effect due to a higher price level, which in turn may decrease the level of output. Thirdly, if the price elasticities of exports and imports are very low, then the trade balance expressed in terms of domestic currency may deteriorate causing a recessionary effect in the economy. In addition to these demand-side effects, there are also a number of supply-side channels through which devaluation can be contractionary. Exchange rate depreciation raises the cost of imported inputs, leading to a decrease in aggregate supply. Additionally, exchange rate depreciation may raise the domestic interest rate and wage level through an increase in the price level.

This might also decrease the aggregate supply in the economy. There are four major empirical approaches in existing studies to investigate the effects of devaluation on output. These are; the control group approach which aims at separating the effect of devaluation from other factors on output; the before and after approach studies changes in country performance at the time of devaluation on output; the macro-simulation approach employs simulation models to analyze the impact of exchange rate changes on output; and the econometric approach applies econometric methods to time series to investigate the effect of devaluations on output. 
The relationships between currency devaluation and output growth have been investigated by a number of studies. But empirical findings of the effects of devaluation on the economy are mixed. Edwards (1986) claimed that devaluations have a negative effect on output in the short-run while they are neutral in the long-run using pooled time series cross-section data for 12 countries. Sheeley (1986) found that devaluations have a negative impact on output for 16 Latin American countries while Nunnenkamp and Schweickert (1990) rejected the hypothesis of contractionary devaluation. Connoly (1983), Gylfason and Schmid (1983), and Taylor and Rosenweig (1984) found a positive relationship between currency devaluation and output expansion. Gylfason and Risager (1984) and Branson (1986) found that currency devaluation is contractionary to the economy. Upadhyaya (1999), did not find any significant long-run effect of currency devaluation on aggregate output for 4 out of 6 Asian countries while he found contractionary effect for two countries.

Bahmani-Oskooee (1998) investigated whether currency depreciation is expansionary or contractionary in 23 LDCs. He found that devaluations have no lung-run effect on output in most LDCs. Bahmani-Oskooee et al. (2002) investigated the effect of currency depreciation on output in Asian countries. They found that in many Asian countries depreciation is contractionary. Chou and Chao (2001) found that currency devaluation leads to a shortrun contractionary effect but has no impact on aggregate output in the long run (except for Indonesia) for 5 Asian countries. Christopoluos (2004) investigated the effect of currency devaluation on output expansion in a sample of 11 Asian countries over the period 1968-1999. He found that, in the long run, in 5 out of 11 countries and for the panel as a whole, depreciation exerts a negative impact on output growth while for three countries depreciation improves growth prospects. Upadhyaya et al. (2004) studied the effect of currency depreciation using panel data and found that while the exchange rate depreciation is expansionary in the short run, it is neutral in the medium and long run.

\section{Methodology}

Following the works of Edwards, 1986; Bahmani-Oskooee, Chomsisengphet and Kandil, 2002; Christopoulos, 2004, we specify the following model:

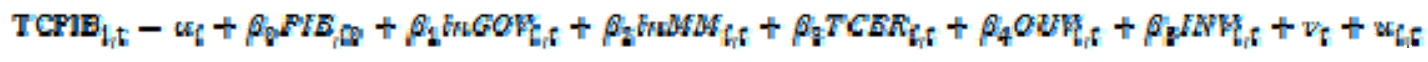

With:

- TCPIBi, t, the annual average growth rate of real GDP(Gross Domestic Product) per capita of country i in the period t;

- PIBi, 0 , the average income of country $i$ in the beginning of period;

- GOVi, $t$, the public spending of country $i$ in the period $t$;

- MMi, t, the money supply of country $i$ in the period $t$;

- TCERi, $t$, real effective exchange rate of country $i$ in the period $t$;

- $\mathrm{OU}_{\mathrm{i}, \mathrm{t}}$, the average ratio of exports to GDP of country $\mathrm{i}$ in the period $\mathrm{t}$;

- INVi, $t$, the average ratio of investment to GDP of country $i$ in the period $t$;

$\alpha_{i}, v_{t}+u_{i, t}$ are respectively, the specific effect in every country, a dumb variable of time and a term of error.

Besides, the sign expected from the average income is negative. This variable shows that if the structural parameters through the preferences and the technology are similar, the poor countries tend to increase faster that the rich countries, this due to the reduction of returns on investment for a given technology. So, there are strengths which contribute to the convergence of the levels of income between countries (Barro and Sala-I-Martin, 1995). The coefficient of average income per capita thus represents the effect of convergence, which would be negative according to the neo-classic theory. According to the theory of endogenous growth, on the other hand, this coefficient would be equal to zero, the effect of convergence were invalid and the savings are not deviating from their permanent growth regime .

The signs expected from the coefficients of public spending and money supply are positive. A monetary or budgetary expansion would boost the economy and would cause an increase in the GDP. We expect that the sign of the real effective Exchange rate is positive. A devaluation of the local currency would stimulate economic activity and increase GDP.

Barro and Sala-I-Martin ( 1995 ) shows that the sign expected from the coefficient on behalf of the investors in the GDP is positive, because the accumulation of the capital is supposed to favor the growth of the real GDP per capita. Also, the countries which open more to the outside experience a stronger growth in the total productivity of factors than those who refuse international competition, because they absorb faster and with more efficiency the technological innovations 
developed abroad (Edwards, on 1993; Barro and Sala-I-Martin, 1995; Rose, 2000; Rose and Van Wincoop, 2001). So, the degree of opening of the economy to the international markets may influence positively the economic growth.

We use the data of 13 African countries of the franc zone (note 4) over the period 1995-2008. These data are pulled by the CD-ROM of the World Bank (World Developpement indicators). The method of estimation is the panel data model.

After the presentation of this model, it is advisable, at the moment to present and to interpret the obtained results.

\section{Presentation and Interpretation of the Main Results}

The model (1) is estimated at first according to the hypothesis of the uniformity of behavior in time and among countries. It means supposing that the coefficients of the model are invariant in time and are identical between countries. We also make the hypothesis that the error is identical and follows the normal law $\mathrm{N}(0, \mathrm{~s})$. We estimate the model by the method of ordinary least squares (OLS).

The specification of the model above implies that the obtained coefficients are identical for 13 considered countries. It is however possible to suppose that there are differences between the countries of the CEMAC in the functioning of their economy. It is thus advisable to adopt a specification highlighting individual effects.

That is why we resume the specification (1) by introducing heterogeneity between countries. We suppose that the coefficients of behavior are identical between countries and invariants in time, with the exception of the constant which we suppose that it is specific in each country. The specific effects appropriate for countries are supposed determinists. We suppose one more time that the errors are identical and follow the normal law $\mathrm{N}(0, \mathrm{~s})$.

The concern at this level is to know if the effects appropriate for countries are significantly different. In other words, the hypothesis of heterogeneity between countries as for the rate of profitability is validated? To verify this hypothesis, we use the test of Fisher as follows:

Under the hypothesis of homogeneity of countries (Ho: $\alpha_{1}=\alpha_{2}=\ldots=\alpha_{12}$ ), the estimated model corresponds to the model with common effects whereas under the hypothesis of presence of heterogeneity (H1: $\exists i, j \exists \alpha_{i} \neq \alpha_{j}$ ), the estimated model is the model with individual effects.

The STATA software proceeds directly to the implementation of the test of Fisher during the estimation of the model with fixed effects. The individual effect $\alpha_{i}$ is considered under the shape $\alpha_{i}=\alpha_{0}+u_{-i}$ the test of homogeneity of countries thus means putting as no hypothesis that all the $u_{-i}$ are invalid. The reading of the test of Fisher above led to accept the hypothesis that all the $u_{-i}$ are invalid $(\mathrm{F}(5,119)=0,85$ and Prob $>\mathrm{F}=0.5166)$. It thus seems that it does not exist between the 13 countries of the Zone Franc individual effects appropriate for each country and which explain his growth rate.

Because the determinist specific effect symbolized by constant values appropriate for every country is not turned out, it could seem more natural to treat this effect as a random and not determinist effect. The model with random effects to be estimated is as follows:

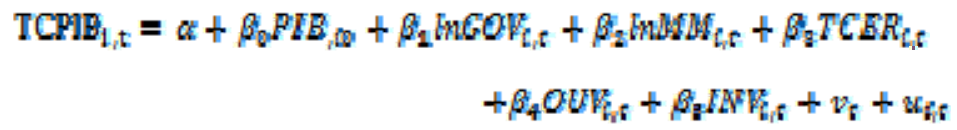

To introduce into the analysis the specific effect and the random effect, we consider that the error, or residue $u_{i t}$, consists of two elements: $\alpha_{\mathrm{i}}$ and $\varepsilon_{\mathrm{it}}$; the first one represents the individual effect, reporting the influence on the growth rate of the variables not taken into account, since these are stable in time; the second represents the influence of the other omitted variables also varying in time from a country to the other. We suppose that the $\varepsilon_{i t}$ are identically and independently distributed and that $\alpha_{\mathrm{i}}$ are not correlated with the explanatory variables. To return the strong results, numerous tests are carried out (see appendix).

The results of various estimations by means of the STATA software are rather close. The test of Fisher indicates that the model is globally significant up to the $1 \%$ threshold (Prob $>\mathrm{F}=0.0000$ ). The quality of the adjustment is averagely acceptable, because the model explains only 59 to $71 \%$ of the total variance. It means that there are other variables, in particular economic which would bring an explanation to the growth rate in the Franc zone.

The table 1 at the end of the paper shows the results of the regressions which served to test the link between devaluation and economic growth in the Franc Zone. It shows that most of the coefficients of the explanatory variables other than the variable relative to the devaluation are statistically significant and with signs that respect the theory. The coefficients of the real GDP per capita, the average rate of the investments in the GDP and the degree of opening are significant and have the expected sign. 
It is necessary to notice that the coefficient of the degree of opening is negative. This explains by the fact that the degree of opening is measured by the ratio of imports to GDP. Now we know that the Franc zone countries import manufactured goods in return of the raw materials which they export. This can have a negative impact on the growth of these countries.

These results also show that the coefficient of the per capita initial average real GDP has a negative sign, which gives evidence of the existence of a conditional convergence.

On the other hand, the investment rate on the GDP has a positive and significant effect on the growth. This confirms the theoretical prediction according to which a level of high investment comes along with a more dynamic growth.

These results also show that the variable which captures the devaluation of the CFA franc (TCER) is significantly different from zero at the beginning of $10 \%$ only in the total model. This shows that the devaluation of the CFA franc has no impact or rather a low impact on the economic growth of the Franc zone countries. This corroborates the results of Edwards (1986) and Bahmani-Oskooee (1998).

Let us recall that the Franc zone knew, before the devaluation of 1994, two types of imbalance: the unemployment, on one hand, and the external deficit, on the other hand. The 1994 devaluation of the CFA francs aimed mainly at three objectives (Bank of France, 1997):

1) The external restoring of the competitiveness of the savings of the zone franc and the recovery of balances of trade;

2) The balancing of the public finances (the reduction of the budget deficits), thanks to an improvement of export products;

3) The resumption of growth, thanks to the resumption of private investment.

The devaluation of the CFA franc of 1994 cannot thus give rise to convincing results, exactly because of two errors, besides common in the history of economic policy: an error of affectation and an error of anteriority.

The error of affectation proceeds because we held three objectives of economic policy for a single instrument (the exchange policy). Although this policy was accompanied with the policy of management of the demand, the rule of Tinbergen was not respected.

As for the error of anteriority, it holds the fact that the Franc zone countries operated first of all a currency adjustment before proposing a series of accompanying measures. Now, it would have been necessary to set up dynamic measures to fight against unemployment before proceeding to a devaluation of CFA francs, exclusively directed to the external objective.

On the cyclical plan, the objective should be that of stabilization of the short-term economy, due to a reduction of the budget deficit (both by an increase of the receipts and in a better control of the spending and in a rebalancing of the common foreign payments (by decreasing the domestic demand).

On the structural plan, the objective would be to implement the reforms intended to increase the efficiency of the economy and the return in a sustainable growth. The specificity of the economic policy in the Franc zone countries should thus be to assure a substantial level of investment, to satisfy the consumption of the populations in the essential goods, because the imbalance which affected the devaluation also proceeded to the absence of development, in other words the lack of adjustment between savings and investment.

Let us note that it is since the mid 80s that most of the Franc zone countries dashed into the programs of structural adjustment under the leadership of the IMF and the World Bank. It seems that all the attempts of real adjustment aimed at reducing the deep economic and financial imbalance appeared during the second half of the $80 \mathrm{~s}$ had failed (Bank of France, 1997).

The incapacity of the governments to reduce the budgetary expenditure which had appreciably progressed in period of economic crisis was translated by a heaviness of the deficits. Besides, several countries continued to resort to external debts to finance the completion of projects thrown during the previous years. It so seems that the devaluation made in such a context could not succeed given that the real adjustment had already failed.

\section{Conclusion}

The report on the failure of the policy of stabilization introduced by the International Monetary Fund in Developing countries led certain authors to revise the efficiency of certain constituents of this economic measure. The policy of currency devaluation is in this line of sight. The objective of the present article was to test the relationship between currency devaluation and economic growth. Our investigations allowed us to conclude that the devaluation of the CFA 
franc had no impact on growth. This absence of impact on the growth is justified by the failure of the structural adjustment programs which should have accompanied the devaluation of the CFA franc.

However, the general question of the nature and the amplitude of the shocks which affect the savings of the WAEMU and the CAEMC countries and the optimality of the answers of "Policy Mix" of both sub-regions, highlight the relevance of the question bound to the extraversion of the monetary management of the BCEAO and the BEAC led de facto by a fastening from the CFA franc to the Euro. So, the logical continuity of the present study would be to bring an answer to the above question.

\section{References}

Agénor P. R. \& Montiel, P. J. (1996). Development Macroeconomics, Princeton University Press, 679

Bahmani-Oskooee, M. (1996). Source of stagflation in an oil-exporting country : evidence from Iran. Journal of Post Keynesian Economics, (18), 609-620. [Online] Available: http://www.jstor.org/pss/4538511

Bahmani-Oskooee, M. (1998). Are Devaluations Contractionary in LDCs? Journal of Economic Development, Vol. 23, pp. 131-144. [Online] Available: http://www.jed.or.kr/full-text/23-1/oskooee.PDF

Bahmani-Oskooee, M., \& Miteza, I. (2003). Are Devaluation Expansionary or Contractionary? A Survey Article, Economic Issues, 8, 1-28.

Bahmani-Oskooee, M., \& Rhee, H. J. (1997), Response of Domestic production to Depreciation in Korea: An Application of Johansen's Cointegration Methodology. International Economic Journal, 11, 103-112. http://dx.doi.org/10.1080/10168739700000029

Bahmani-Oskooee, M., Chomsisengphet, S. \& Kandil, M. (2002). Are Devaluations Contractionary in Asia? Journal Of Post Keynesian Economics, Vol. 25, pp. 67-81.

Banque de France (1997). Note d'information $n^{\circ} 106$, Direction de la Communication, mars.

Chou, L. W. \& Chao, C. C. (2001). Are currency devaluations effective? A panel unit root Test, Economics Letters, Vol.72, pp.19-25. http://dx.doi.org/10.1016/S0165-1765(01)00399-8

Christopoulos, D. K. (2004). Currency devaluation and output growth: new evidence from panel data analysis, Applied Economics Letters, Vol.11, pp.809-813. http://dx.doi.org/10.1080/1350485042000254647

Connolly, M. (1983). Exchange Rates, Real Economic Activity and the Balance of Payments: Evidence from the 1960s. In Classen E. and Salin P., eds., Recent Issues in the Theory of the Flexible Exchange Rates. Amsterdam: North-Holland.

Cooper, R. N. (1971). Currency devaluation in developing countries. in Government and Economic Development, ed. R. G. New Haven: Yale UP.

Diaz-Alejandro, C. F. (1963). A note on the impact of devaluation and the redistributive effects. Journal of Political Economy, (71), 577-580. http://dx.doi.org/10.1086/258816

Eboué, C. (1998). Le franc CFA à l'heure de l'euro: le temps de la réforme est-il-arrivé? in Hammouda H.B. et Kasse M.(ed.), l'avenir de la zone franc, Codesria-Karthala.

Edwards, S. (1986). Are Devaluations Contractionary? Review of Economics and Statistics, 68, 501-508. http://dx.doi.org/10.2307/1926028

Edwards, S. (1989). Exchange controls, devaluations and real exchange rates : The Latin American Experience, Economic Development and Cultural Change, (37), 457-494. [Online] Available: http://www.econ.ucla.edu/workingpapers/wp450.pdf

Gylfason, T. (1987). Credit policy and economic activity in developing countries with IMF stabilization programs, Princeton Studies in International Finance, (60). http://dx.doi.org/10.1016/0014-2921(84)90070-9

Gylfason, T. \& Risager, O. (1984). Does devaluation improve the current account?, European Economic Review, Vol. 25, pp.37-64.

Gylfason, T. \& Schmid, M. (1983). Does devaluation cause stagflation?, Canadian Journal of Economics, Vol. 16, pp. 641-54. http://dx.doi.org/10.2307/135045

Kamin, S. B. and Rogers, J. H. (1997), "Output and the Real Exchange Rate in Developing Countries: An Application to Mexico", Board of Governors of the Federal Reserve System (U.S.), International Finance Discussion Papers: 580. 
Krueger, A. (1978). Foreign Trade Regimes and Economic Development: Liberalization Attempts and Consequences, Cambridge, MA : Ballinger.

Krugman, P. \& Taylor, L. (1978). Contractionary effect of devaluation, Journal of International Economics, Vol.8, pp.445-56. [Online] Available:

http://www.elsevierscitech.com/pdfs/np2008/contractionaryeffects.pdf

Morley, S. A. (1992). On the Effect of devaluation during Stabilization Programs in LDCs. The review of Economics and Statistics, (74(1)), 21-27.

Nashashibi K. \& Bazzoni, S. (1994). Exchange Rate Strategies and Fiscal Performance in Sub-Saharan Africa, IMF Staff Papers, vol.41, 1, 76-122. http://dx.doi.org/10.2307/3867486

Nunnemkamp, P., \& Schweickert, R. (1990). Adjustment Policies and Economic Growth in Developing Countries. Is Devaluation Contractionary? Weltwirtschftliches Archive, Vol. 126, pp.474-493. http://dx.doi.org/10.1007/BF02709032

Sheehey, C. A. (1986). Unanticipated Inflation, Devaluation, and Output in Latin America, World Development, Vol.14, pp. 665-71. http://dx.doi.org/10.1016/0305-750X(86)90131-2

Taylor, L. \& Rosensweig, J. (1984). Devaluation, Capital Flows and Crowding Out: A CGE Model with Portfolio Choice for Thailand, Working paper, The World Bank.

Upadhyaya, K. P. (1999). Currency Devaluation, Aggregate Output, and the Long Run: An Empirical Study. Economics Letters, 64, 197-202. http://dx.doi.org/10.1016/S0165-1765(99)00088-9

Upadhyaya, K. P., Mixon, F. G. \& Bhandari, R. (2004). Exchange rate adjustment and output in Greece and Cyprus: evidence from panel data. Applied Financial Economics, Vol.14, pp.1181-1185. http://dx.doi.org/10.1080/0960310042000282058

\section{Notes}

Note 1. The African Countries of the Franc Zone are grouped together in two monetary unions namely:

- The West-African Economic and monetary Union (WAEMU), which includes: Benin, Burkina Faso, Cote d'Ivoire, Guinea-Bissau, Mali, Niger, Senegal and Togo. These countries have a common central bank, the Central Bank of the States of western Africa ( BCEAO), which emits a common currency, CFA franc (African Financial Community Franc);

- Central Africa Economic and Monetary community (CAEMC), which account six countries: Cameroon, Congo, Gabon, Equatorial Guinea, Central African Republic and Chad. These countries also have a unique central bank, the Bank of the States of Central Africa (BEAC), which emits the common currency the common currency the CFA franc (Franc of the Financial Cooperation in Central Africa).

Note 2. In the present article, the exchange rate means the number of domestic monetary units which can be exchanged with a foreign monetary unit. So, the devaluation of the local currency implies that would be needed more local monetary units to hold a foreign monetary unit. It also is to note that no distinction is made between the regimes of exchange. So, devaluation and currency depreciations are quite treated in the same way and considered as a positive variation of the exchange rate.

Note 3. The «doctrine of Abidjan ", still called "doctrine Balladur", was especially theorized and applied from 1993 when it was allowed that no Franc zone African country in delicacy with the conditionality's of the International Monetary Fund and lor the World Bank would know how to aspire to a French financial support. To know more about it, see B. Owl, «The economic policy of France in zone franc ", African Politics (Policy), n 58, in June, 1995, p. $25-40$

Note 4. We shall not take into account Guinea-Bissau which adhered to the franc zone on May 02nd, 1997 
Table 1. Results of the regressions of the link between the devaluation of the CFA franc and output growth in the Franc

\begin{tabular}{|c|c|c|c|}
\hline Variables & OLS & Fixed effects & Random Effects \\
\hline \multirow[t]{2}{*}{$\mathrm{PIP}_{0}$} & $-0,858$ & $-12,424^{* * *}$ & $-0,975^{* *}$ \\
\hline & $(-2,251)$ & $(-6,616)$ & $(-2,204)$ \\
\hline \multirow[t]{2}{*}{ GOV } & $2,096^{*}$ & 2,520 & 2,468 \\
\hline & $(1,953)$ & $(0,987)$ & $(0,695)$ \\
\hline \multirow[t]{2}{*}{$\mathrm{MM}$} & $-16,546^{* * *}$ & $-11,446 * *$ & $-19,636^{* *}$ \\
\hline & $(-3,177)$ & $(-2,074)$ & $(-2,386)$ \\
\hline \multirow[t]{2}{*}{ TCER } & $2,096^{*}$ & 2,520 & 2,468 \\
\hline & $(1,953)$ & $(0,987)$ & $(0,695)$ \\
\hline \multirow[t]{2}{*}{ OUV } & $-1,327 * *$ & $-3,846^{* *}$ & $-2,077 * * *$ \\
\hline & $(-2,048)$ & $(-2,844)$ & $(-2,482)$ \\
\hline \multirow[t]{2}{*}{ INV } & $2,602^{* * *}$ & $4,159 * *$ & $3,134 * * *$ \\
\hline & $(4,411)$ & $(4,745)$ & $(3,799)$ \\
\hline \multirow[t]{2}{*}{ Constante } & $-7,941$ & 90,352 & $-2,341$ \\
\hline & $(-1,548)$ & $(5,288)$ & $(-0,344)$ \\
\hline Size & 195 & 195 & 195 \\
\hline Adjusted $\mathrm{R}^{2}$ & 0,59 & 0,71 & 0,68 \\
\hline
\end{tabular}

The triple, double and simple asterisks indicate thresholds of statistical meaning of $1 \%, 5 \%$ and $10 \%$ respectively.

Appendix. Robustness tests of the results

Breush-Pagan test of absence of random effects

Test the absence of individual specific effects means making out a will the nullity of their variance: Ho: $\alpha_{i}=0$ against $\mathrm{H} 1: \alpha_{\mathrm{i}} \neq 0$.

The implementation of the test of Breusch-Pagan in STATA leads to the result below. We are so brought to accept the no hypothesis of presence of specific effects because chi2 $(1)=0.41$ and Prob $>$ chi2 $=0.5204$. In this stage of the process, it seems that it is necessary to consider the specific effect of countries not under the random, but good shape under the headlines train determinist.

The multiplier of Breusch and Pagan Lagrangian test for random effects:

t_rtbte $[$ ident, $\mathrm{t}]=\mathrm{Xb}+\mathrm{u}[$ ident $]+\mathrm{e}[$ ident, $\mathrm{t}]$ Estimated

results:

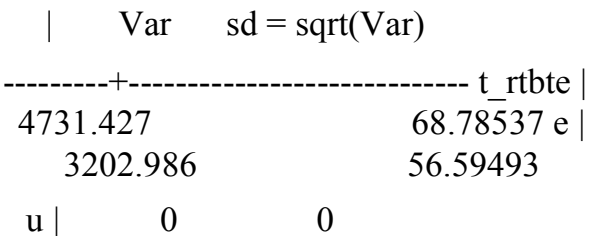

Test: $\quad \operatorname{Var}(\mathrm{u})=0$

$$
\begin{array}{cc}
\operatorname{chi} 2(1)= & 0.41 \\
\text { Prob }>\text { chi } 2= & 0.5204
\end{array}
$$

\section{Validity of the hypothesis of exogeneity of the explanatory variables}

A hypothesis made during the estimation of the model (2) is the absence of correlation between the specific effects and the explanatory variables. Under this hypothesis, the obtained valuer is the best valuer of the model; on the other hand 
the presence of correlation leads a not convergence of this valuer. It seems from then on crucial to wonder about the exogenous character of the explanatory variables. The test of Hausman brings an answer to this concern.

The implementation of the test of Hausman in STATA gives the following results. The coefficients $(\mathrm{b})$ are the estimations LSDV and ( B ) the estimations MGC. The statistics of Hausman is supplied and is worth 3.84; towards his $\mathrm{p}$ - been worth (Prob $>$ chi2 $=0.7979$ ), it is advisable to accept the hypothesis of nearness of the coefficients LSDV and MGC: we end then in the acceptance of the hypothesis of existence of correlation between the explanatory variables and the random specific effect. The test thus leads to accept the model with random effects against the model with fixed effects.

\section{Hausman Fixed}

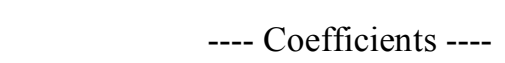

\begin{tabular}{|l|l|l|l|l|}
\hline & (b). & (B) & $\begin{array}{l}\text { (b-B) } \\
\text { difference }\end{array}$ & $\begin{array}{l}\text { sqrt(diag(V_b-V_B })) \\
\text { S.E. }\end{array}$ \\
\hline PIB $_{0}$ & -134.106 & -234.4484 & 100.3424 & 110.5376 \\
\hline GOV & 31.81338 & 29.66131 & 2.152068 & 7.575718 \\
\hline MM & 11.11455 & 44.23006 & -33.1155 & 57.784 \\
\hline TCER & 3.175822 & 3.116254 & .0595688 & .4071037 \\
\hline OUV & 1.910594 & 1.203147 & .7074476 & .9764144 \\
\hline INV & -12.81801 & 3.721936 & -16.53994 & 73.51435 \\
\hline \multicolumn{5}{|c|}{$\mathrm{b}=$ consisting under Ho and Ha; obtained from xtreg } \\
B $=$ weak under Ha, efficient under Ho; obtained from xtreg
\end{tabular}

Test: Ho: non systematic difference of the coefficients

$$
\begin{aligned}
\operatorname{chi} 2(7) & =(b-B)^{\prime}\left[\left(V_{-} b-V_{-} B\right)^{\wedge}(-1)\right](b-B) \\
& =3.84 \\
\text { Prob }>\text { chi } 2 & =0.7979
\end{aligned}
$$

\section{The test of normality}

We use the test of Shapiro-wilk swilk resid

Shapiro-Wilk W test for normal data

\begin{tabular}{ccccccc} 
Variable | Obs & W & V & z & \multicolumn{2}{l}{ Prob $>$ Z } & \\
- & 0.92791 & & 7.521 & 4.544 & 0.00000 &
\end{tabular}

With one $\mathrm{p}$ - been worth been neighbor of zero, we conclude that residues follow the normal law. 